\title{
Probiotics Role in Control of Avian Coccidiosis
}

\author{
Muhammad Anas ${ }^{1 *}$ Hafiz Muhammad Rizwan ${ }^{2}$ and Muhammad Kasib Khan ${ }^{2}$ \\ ${ }^{1}$ Faculty of Veterinary Science, University of Agriculture, Pakistan \\ ${ }^{2}$ Department of Parasitology, University of Agriculture, Pakistan
}

Submission: April 06, 2018; Published: July 11, 2018

*Corresponding author: Muhammad Anas, Faculty of Veterinary Science, University of Agriculture, Faisalabad-38040, Pakistan, Tel: +92-306-2365100; Email: muhammadanas2365@gmail.com

\begin{abstract}
Cereal products fermented by lactic acid bacteria are documented first in Egypt and Iraq during 2000-3000 B.C. These are one of the oldest fermented foods. In 1907, Elie Metcnikoff was the first scientist who not only observe but also put forward the scientific basics of fermentation. Then to explore gut bacteria intensive researches were made in late 1940s. In $2006 \mathrm{FAO}$ and WHO give the complete definition of probiotics, living microbes beneficial for health provided in feed. For treatment of Coccidiosis probiotic combinations of different microbes such as Lactobacillus, Bifidibacterium and Streptococcus are used now a day. Coccidiosis, a parasitic disease mainly of poultry sector, caused by Eimeria specie's. Coccidiosis causes serious damage to the intestinal epithelium resulting in diarrhea. This problem can be effectively controlled by the use of feed probiotics.
\end{abstract}

Keywords: Cereal; Fermentation; Probiotics; Coccidiosis;Bifidibacterium; Lactobacillus; Streptococcus; Diarrhea; Geese; Duck; Sporozoits; Parasite; Hydrogen peroxide; Ammonia; Pedicoccus; Chemotherapy

\section{Introduction}

Poultry include duck, geese, chicken and guinea fowl as domesticated birds which are mainly raised for eggs and meat purpose. Now days in Pakistan, poultry industry is flourishing with its maximum as layer population has been increased from 9.5 million (1995) to 27.50 million (2010). Similarly, broiler production has been increased from 72.80 million (1991) to 785 million (2010). These facts and figures shows how effectively and efficiently poultry industry is flourishing in Pakistan [1]. Eimeria, apicomplexan parasite, major cause of avian coccidiosis. There are about seven different species of Eimeria which not only cause disease in poultry but also in different domestic animal species such as cattle, dogs and cats. But it causes major economical loss to the poultry industry in Pakistan. Species of Eimeria causes coccidiosis in poultry industry are E. necatrix, E. miti, E. acervulina, E. tenella, E. maxima, and E. brunette [2].

Most of the times accidental ingestion of Eimeria oocysts cause disease in younger birds. Oocyst excyst into sporozites in lumen of upper intestine. Sheded in feaces as environmental resistant oocyst after different developmental stages in host. As Eimeria species affect intestinal epithelium resulting into enteritis and diarrhea. Severity of this dependent upon specie of the Eimeria. Coccidiosis also lead to secondary infection due to immune suppression cause by it. Most of the time it is controlled by management, chemotherapy and biological agents [3]. Life cycle of coccidiosis is very short almost of about 4-6 days. There are both sexual and asexual stages in life cycle of Eimeria. In asexual stages of the life cycle, trophozoites advance to shizionts and then merozoites respectively known as as shizogony and merogony. Sexual stage includes the formation of zygote by fusion of micro and macro gametes. This zygote further yields environmental resistant oocyst released in feaces [4].

Infected water or feed ingestion lead to development of coccidiosis. Enzymatic action in intestine after swallowing of oocyst from infected feed or water source lead to the liberation of sporozoits, this process is known as excystation. In intestine sporozoites invade enteric epithelial cells where further invasion to glands takes place by macrophages and further development occur there [5]. Eimeria's oocysts are very hard and resistant to degradation by mechanical and chemical sources. Even proteolytic degradation of oocyst is very difficult. Oocyst can survive up to 7 months in non-infective un-suporulated form. But on suporulation it becomes ineffective [6].

\section{Control Strategies}

Medicinal strategies for Eimeria control involved the use of amprolium along with polyeaster ionophores in higher doses. 
Moreover live attenuated or un-attenuated vaccinal strains can also be used for the control of coccidiosis. Anti-coccidials further categorized into ionophores and synthetic chemicals. Ionophores interferes with ions transfer through plasma membrane of the parasite. This lead to the death of the parasite. Synthetic drugs interfere with biochemical pathways in parasite. But due to massive introduction of medicines in different combinations, resistance has been developed in the poultry birds. This is the serious problem as no other drug has been introduced along with above mentioned drugs for the control of coccidiosis.So,to combat this problem live Eimeria oocysts have been used as live vaccine. This lead to severe problem in broiler flock due to poor management [7-9]. We use herbals and botanicals as an alternative strategy to control coccidiosis as these are cheaper, effective and safer as compared to attenuated vaccines. As these are naturals so no resistance has been detected against them till yet. Now days we use culture of different microbes in feed in order to improve the indigenous microflora of the host [10].

\section{Support from Literature}

Scientific studies had shown that primalac, lactobacillus preparation, proved effective against E. acervulina. As it enhance lymphocyte production in epithelial cells of the host if given six weeks after birth [11]. Parasitologists had also performed experiments by using the commercial preparation, Mitomax, a pedicoccus and saccharomyces combination. It provided good results against E. acervulina and E. tenella. Tierney was the scientist who studied competitive exclusion of Eimeria species by lactobacillus bacteria obtained from the guts of the chicken. He performed all these studies in invitroenvironment [12]. Similarly, many other scientists have observed the effect of probiotics contain pedicoccs and lactobacilli. These probiotics not only improve the growth of birds effected with coccidiosis but also proved helpful in reducing the resistance against medication.These probiotics actually produce substances like hydrogen peroxide and ammonia which inhibit the growth of these pathogenic microbes [13].

Different commercial preparations of probiotics available in market proved effective against coccidiosis. Pediococcus acidlactici, gram positive homo-fermentive bacteria, proved very effective in maintaining the $\mathrm{pH}$ of chicken gut. This also inhibit growth of Eimeria species there [14].

\section{Conclusion}

Coccidiosis has caused huge economic loss to our poultry industry just due to loss bird's weight or by retarded growth of the birds. So, in order to control that negative effects probiotics have proved very effective. As resistance had been developed against many drugs. So, it is worthwhile to use probiotics in order to remove Eimeria species by competitive exclusion.

\section{References}

1. Hameed T (2017) Study on current status and future trends of commercial poultry production in Pakistan. Pure and Applied Biology, 6: 1 .

2. Ayaz MM, Akhtar M, Hayat CS, Hafeez MA, Haq AU (2003) Prevalence of coccidiosis in broiler chickens in Faisalabad. Pakistan, Pak Vet J 23: 51-52.

3. Moorthy M, Mehala C (2008) Effect of Aloe vera and Curcuma longa (Turmeric) on Carcass Characteristics and Biochemical Parameters of Broilers. International Journal of Poultry Science 7(9): 857-861.

4. McDougald LR (2003) Coccidiosis in Poultry Diseases. In: Saif YM, Barnes HJ, Fadly AM, Glisson JR, McDougald LR, Swayne DE, (Eds.), Iowa State Press, Iowa, USA, pp. 974-991.

5. Jeurissen SHM, Veldman B (2002) The interaction between feed (components) and Eimeria infection in poultry health and in Nutrition and Health of the Gastrointestinal Tract. In: Blok MC, Vahl HA, de Braak L, Hemke G, Hessing M (Eds.), Wageningen Academic Publisher, Wageningen, The Netherlands. pp. 159-182.

6. Belli S, Smith N, Ferguson D (2006) The coccidian oocyst: a tough nut to crack! Trends in Parasitology 22(9): 416-423.

7. Chapman HD (2000) Practical use of vaccines for the control of coccidiosis in the chicken. World's Poultry Science Journal 56: 7-20.

8. Chapman HD, Cherry TE, Danforth HD, Richards G, Shirley MW, et al. (2002) Sustainable coccidiosis control in poultry production: The role of live vaccines. Int J Parasitol 32(5): 617-629.

9. Chapman HDB, Roberts MW, Shirley, Williams RB (2005) Guidelines for evaluating the efficacy and safety of live anticoccidial vaccines and obtaining approval for their use in chickens and turkeys. Avian Pathol 34(4): 279-290.

10. Quiroz-Castañeda R, Dantán-González E (2018) Control of Avian Coccidiosis: Future and Present Natural Alternatives.

11. Dalloul RA, Lillehoj HS, Shellem TA, Doerr JA (2003) Enhanced mucosal immunity against Eimeria acervulina in broilers fed a Lactobacillusbased probiotic. Poult Sci 82(1): 62-66.

12. Tierney J, Gowing H, Van Sinderen D, Flynn S, Stanley L, et al. (2004) In vitro inhibition of Eimeria tenella invasion by indigenous chicken Lactobacillus species. Veterinary Parasitology 122(3): 171-182.

13. Ritzi M, Abdelrahman W, Mohnl M, Dalloul R (2014) Effects of probiotics and application methods on performance and response of broiler chickens to an Eimeria challenge. Poultry Science 93(11): 2772-2778.

14. Klaenhammer TR (1993) Genetics of bacteriocins produced by lactic acid bacteria. FEMS Microbiol Rev 12(1-3): 39-85. 


\section{Your next submission with Juniper Publishers will reach you the below assets}

- Quality Editorial service

- Swift Peer Review

- Reprints availability

- E-prints Service

- Manuscript Podcast for convenient understanding

- Global attainment for your research

- Manuscript accessibility in different formats

( Pdf, E-pub, Full Text, Audio)

- Unceasing customer service

Track the below URL for one-step submission https://juniperpublishers.com/online-submission.php 